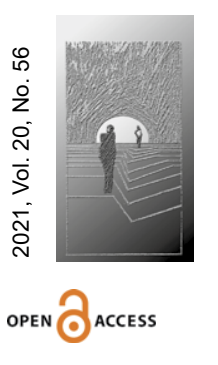

\title{
Humanities Studies and Jesuit Principles of Education
}

\begin{abstract}
RESEARCH OBJECTIVE: The objective of the study is to identify key features of the concept of analysing humanitarianism and, eventually, humanity as an important sociogenic factor and its meaning for contemporary education.
\end{abstract}

RESEARCH PROBLEM AND METHODS: The concept of human tradition is discredited as an anachronism in the current paradigm of education which is professionally oriented. What is more, the contemporary concept of humanities or humanism is unclear in its definition, which is the source of tensions in the current discourse on humanistic education. This work focuses on recognizing the conceptual core in the humanist tradition through the analysis of the ancient and Renaissance idea of the study of humanitarianism that dominated in the educational paradigm in the period of the Renaissance humanism and in the development of Jesuit education.

THE PROCESS OF ARGUMENTATION: The study indicates interpretative inconsistency in the concept of modern humanism. Trying to explain what is unclear in the humanistic discourse, the author will, first of all, focus on the origin of the Renaissance humanism with its outdated concept of the study of humanitarianism, and then he will present the analysis of the concept of the original, ancient understanding of the study of humanitarianism in the inspiring text of the Renaissance humanistic movement Pro Archia Poeta Oration by Cicero. Finally, the author presents the connection between the analysis of humanitarianism and the Renaissance educational system of Societas Jesu, as well as the perspectives of this tradition and its influence on the present time.

RESEARCH RESULTS: In the research, the author identified the ancient and Renaissance concept of studying humanitatis as a key sociogenic factor necessary for the morphogenesis of cultural identity. Humanity, as a dynamic anthropological constant necessary for the life of a polis should be the central point of all forms of the current educational paradigms.

CONCLUSIONS, INNOVATIONS, RECOMMENDATIONS: Humanistic studies, as a lifelong process of cultivating cura personalis according to Jesuit principles, are an important condition for upgrading humanity which is characterized by the fulfillment of the moral dimension of an individual integrated with social and cultural processes of the society. The study indicates the meaning 


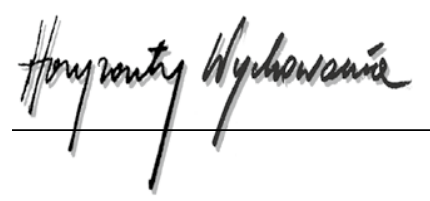

of the epideictic approach to analysing humanitarianism in its function of articulating the cultural identity of the polis.

\section{$\rightarrow$ KEYWORDS: HUMANITAS, STUDIA HUMANITATIS, HUMANISMUS, CURA PERSONALIS, UPBRINGING}

\section{STRESZCZENIE:}

\section{Studia humanistyczne i jezuickie zasady wychowania}

CEL NAUKOWY: Celem pracy jest identyfikacja kluczowych cech koncepcji badania humanitaryzmu i ostatecznie ludzkości jako istotnego czynnika socjogennego oraz jego znaczenia dla współczesnej edukacji.

PROBLEM I METODY BADAWCZE: Pojęcie tradycji ludzkiej jest dyskredytowane jako anachronizm w obecnym paradygmacie edukacji zorientowanej zawodowo. Co więcej, obecne pojęcie humanistyki czy humanizmu jest niejasne definicyjnie, co jest źródłem napięć w aktualnym dyskursie o edukacji humanistycznej. Praca koncentruje się na rozpoznaniu rdzenia ideowego tradycji humanistycznej poprzez analizę starożytnej i renesansowej koncepcji studium humanitaryzmu, która dominowała w paradygmacie edukacyjnym w okresie humanizmu renesansowego oraz w rozwoju oświaty jezuickiej.

PROCES WYWODU: Studium wskazuje na niespójności interpretacyjne w koncepcji współczesnego humanizmu. Próbując wyjaśnić niejasności w dyskursie humanistycznym, w pierwszej kolejności skupi się na genezie renesansowego humanizmu z jego przestarzałą koncepcją nauki o humanitaryzmie, a następnie przedstawi analizę koncepcji pierwotnego, starożytnego rozumienia nauki o humanitaryzmie $w$ inspirującym tekście renesansowego ruchu humanistycznego Pro Archia Poeta Oratio Cycerona. Na zakończenie opracowania pokazuje związek między badaniem humanitaryzmu a renesansowym systemem edukacyjnym Societas Jesu, a także współczesne perspektywy tej tradycji.

WYNIKI ANALIZY NAUKOWEJ: W badaniu zidentyfikowano starożytną i renesansową koncepcję badania humanitatis jako kluczowego czynnika socjogennego niezbędnego do morfogenezy tożsamości kulturowej. Ludzkość jako dynamiczna stała antropologiczna niezbędna do życia polis powinna być centralnym punktem wszelkich form aktualnych paradygmatów edukacyjnych.

WNIOSKI, INNOWACJE, REKOMENDACJE: Studia humanistyczne jako całożyciowy proces kultywowania w duchu jezuickiej zasady cura personalis są ważnym warunkiem aktualizacji człowieczeństwa, które charakteryzuje się realizacją moralnego wymiaru jednostki zintegrowanej z procesami społecznymi i kulturowymi społeczeństwa. Studium wskazuje na znaczenie epidyktyczności badania humanitaryzmu w jego funkcji artykułowania tożsamości kulturowej polis.

SŁOWA KLUCZOWE: HUMANITAS, STUdIA HUMANITATIS, HUMANIZM, CURA PERSONALIS, WYCHOWANIE 


\section{Introduction}

The tradition of interpreting the Renaissance humanism and the concept of the study of humanitarianism was marked with a series of historiographical clichés that became the subject of controversy and revision in the second half of the 20th century. One of typical interpretative clichés is understanding the intellectual movement related to the Renaissance analysis of humanitarianism as an ideological revolution. In this interpretation, humanistic studies are to represent a systematic opposition aiming at breaking with the medieval culture and offering an alternative for the scholastic tradition of university education. In the light of the current analysis of the Renaissance humanism, such understanding is difficult to maintain. Already in 1950s, Kristeller and others documented a complex tangle of medieval influences coming to Italy in the $13^{\text {th }}$ century, especially from more culturally advanced French regions of the medieval Europe. Such continuity of the medieval receptions of antiquity, which were of humanitarian nature, was so popular that some researchers were even ready to believe that the Renaissance concept is no longer reasonable to maintain (cf. Kristeller, 1944-1945).

Ideological tendencies of cultural wars in the 19th century made people understand the Renaissance humanism as a rebellion of lay trends against scholasticism perceived as a leading culture of the medieval Christianity and as an attempt to free the lay worldview from the influence of the medieval Christian paradigm. Such understanding of the Renaissance humanism was probably influenced by the incorrect interpretation of $\mathrm{Pe}-$ trarch's scholasticism in his De sui ipsius et multorum aliorum ignorantia. Also, in this case, more detailed analysis of Petrarch's objections against the scholastic Aristotelianism indicated that they were actually directed towards some elements of Averroist interpretations of Aristotle's ideas which, according to Petrarch, were problematic due to their inconsistency with the Christian teaching. What is more, in De sui ipsius et multorum aliorum ignorantia, Petrarch attacks scholastic philosophers' tendency to adore Aristotle as an infallible authority equal to the Church's teachers. For Petrarch, Aristotle, with all due respect for ancient philosophers, was just a pagan thinker who, just like any other mortal, made mistakes. Actually, Petrarch did not attach scholasticism as much as some scholastic researchers attacked scholastic paradigms (cf. Hankins, 2007, pp. 4145). We may see that interpreting Petrarch as a defender of the Christian thought stands in direct opposition with the ideal which Petrarch tried to achieve in his life and work.

The dispute between Renaissance humanists and the scholastic practice probably contributed to the appearance of another popular cliché: there was a tendency to interpret the Renaissance humanism as a more or less articulated philosophical approach which was an alternative to scholastic ideological variants. At the beginning of the 15th century, Giovanni Conversini da Ravena and Pier Paolo Vergerio started to present humanist studies as a specific educational programme (cf. Kohl, 1992, p. 194) which, in Jesuit educational systems, appeared at the end of the 16th century (cf. Kohl, 1992, p. 201; Kristeller, 1944-1945, p. 365). The gradual canonization of the curriculum of teaching humanities was crystallized in five disciplines: grammar, rhetoric, poetry, history 


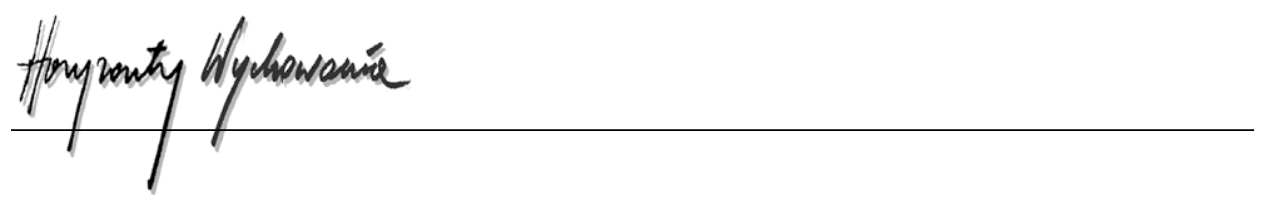

and moral philosophy. This may suggest that the concept of a philosophical nature of humanist studies is, to some degree, right: we can see that, to some extent, these disciplines match the contents of the classical septem artes liberales which belonged to the philosophical propaedeutics. However, we should remember that in the scholastic taxonomy of sciences, moral philosophy was one of practical disciplines based on applying the principles of hierarchically higher disciplines of the philosophy of nature and metaphysics, i. e. disciplines that were higher in the hierarchy of a philosophical science. The analysis of the literary output of all important humanists indicated that philosophical treatises, mainly oriented at selected subjects of moral philosophy, constituted only one per mill of the whole humanistic literature. Thus, Kristeller emphasizes that humanists were not simply philosophers, but writers (cf. Kristeller, 1944-1945, p. 353).

Another interesting interpretative issue related to the relationship between humanities and professionalism is whether the concept of humanities represents the Aristotelian philosophical contemplation necessary for the achievement of eudaimonia, or whether it is more similar to the ideal of an active citizen entering into the reality of social and political events in the social space. In Pro Archia, Cicero presents Archias, the poet, as someone who devoted himself to humanistic studies in the isolation from the public noise (cf. Cicero, 1979, p. 6). Humanists are often presented as overactive actors of culture, but Davies notices that the key aspect of identity of a practitioner of humanism is being a reader (cf. Davies, 2001, p. 91). Under the influence of the authority of Burckhardt's works from the second half of the 19th century (cf. Burckhardt, 1961), many people believed that the Renaissance humanism was a turn to an individual interior in a self-reflective emancipation of an individual, as opposed to the uniform social normativeness (cf. Hankins, 1995, p. 310). Hans Baron (cf. Baron, 1955, 1989) disturbed this historiographical motif in the middle of the 20th century when he started to discuss his thesis on politically involved civil humanism.

\section{Humanist studies as a cultural reform of Renaissance}

In 1333, Francesco Petrarch discovered in a monastic library in the Principality of Liège a missing manuscript of Cicero's defense speech Pro Archia Poeta Oratio (cf. Cicero, 1979). The transcription of that ancient text became one of the main sources of the insemination of the concept of the humanitatis study (cf. Clark, 1921, p. 18), which gradually spread in European education within the next two centuries. In a broader sense, the Latin word humanitas means humanity, human nature, and, in a broader sense, it also means refinement, education or politeness (contrary to impolite or barbarian behaviour). Thus, the expression "studium humanitatis" refers to studying cultivated humanity. A typical feature of the developing humanism of the 14th century was that Cicero's imperative of studying literature was perceived by Renaissance writers as a call for studying ancient literature. Therefore, humanist studies were indispensably related to studying Latin. The humanistic project introduced the idea of a linguistic training traditionally 
applied in grammar and rhetoric. What was new was the acknowledgement of the central role of aesthetics with reference to the contents of speech and, ultimately, with reference to the character of the speaker himself. Apart from the fact that Petrarch's cultural programme followed the proto-humanistic orientations of the second half of the $12^{\text {th }}$ century, it was him who, under the influence of Cicero's rhetoric heritage, formulated humanistic studies as a relatively defined cultural and social programme that emphasized the moral dimension of humanity. According to Petrarch, studying the Latin grammar, literature and rhetoric changes a person's tool that is purely utilitarian and oriented at a career in public administration into a tool for lifelong cultivation of the character of a human being as a moral creature. In this way, Petrarch's analysis of ancient culture becomes a matter of humanity.

Renaissance humanists believed that through the elaboration of a programme of studying humanism, they will revive the ancient ideal. Thus, we assume that a closer look at the source of inspiration used by Petrarch and other writers may provide us with important information concerning the analysed issues. As we have already mentioned, an important milestone in the origin of the Renaissance studies on humanism was the study of Cicero's Pro Archia which, with its content and form, determined the shape of the developing humanistic project.

\section{The concept of studia humanitatis in Pro Archia Poeta Oratio}

In 62 B.C. Marcus Tullius Cicero gave a speech in defence of a poet named Archias in front of the Roman Court Assembly. Aulus Licinius Archias, a Greek poet of a Syrian origin from Antioch, was a protégé of a Roman politic Lucius Licinius Lucullus and a former mentor and teacher of Cicero himself. The objective of the process was questioning Archias' claim for a Roman citizenship. At first, Cicero deals with the actual nature of Archias' civil status, but, knowing that there are no documents that confirm that status, Cicero moves the emphasis of the whole defence towards a more general issue. The basis of his main line of argumentation is a surprising narrative turn when he comes up with the idea that Archias does not have to be a Roman citizen, but it is Rome which needs Archias (cf. Cicero, 1979, p. 8). Rome needs Archias as a poet and a writer.

However, in case of Archias, a standard tactics of a diversion of theme required a more serious infringement of the usual narrative of the legislative environment of the Roman Republic. The character of Pro Archia is unusual for the court processes of the 4th century B.C. Aristotle distinguishes three kinds of rhetoric: a) forensic or forensic judicial rhetoric, b) a negotiating political speech, and c) a solemn celebration rhetoric (cf. Aristoteles, 2009, p. 39). This division into rhetoric kinds results from different objectives of speech connected with specific areas of social life: a kind of speech aims at a) benefit or damage to which the speaker encourages or discourages the listeners; judicial speech is to cause b) justice or injustice; and the objective of a solemn rhetoric is to c) approve or disapprove of something that is morally good or bad (cf. Aristoteles, 


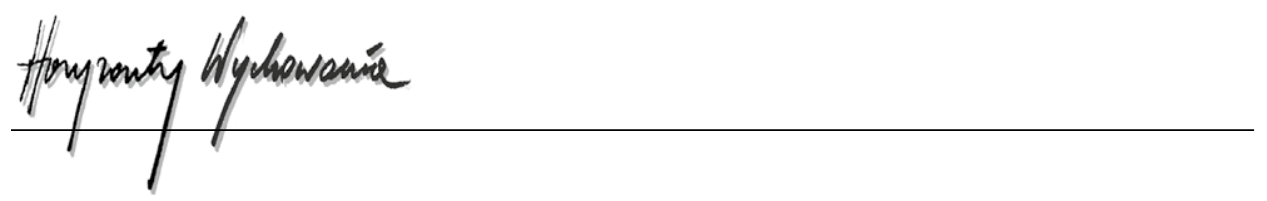

2009, p. 39). Cicero's infringement in Pro Archia consisted in the incorrect adjustment of a rhetorical kind to the situation which, in that case, was a court dispute that required a judicial utterance. In his apology, Cicero suddenly moves from the judicial speech to epideixis, i.e. to the ceremonial rhetoric, which is determined by objectives other than the judicial speech and uses different methods and various styles.

Despite its brevity, the Pro Archia defence speech is a subtle and complex composition of a few meaning layers, with references to a broad cultural and political context. Cicero's rhetoric intelligence is reflected in the fact that a very formal side of the defence oscillates among different rhetoric genres with their particular objectives, methods and styles, which expresses the main idea of the whole defence. Cicero addresses educated audience which mainly includes experts in rhetoric, and, already in the exordia, he emphasizes the non-orthodox nature of his approach assuming that his listeners will be able to "read" the aim of the non-standard formal structure of his speech.

From the point of view of the considerations on the concept of humanity, apart from the basic and ordinary plan of a judicial speech, epideictic fragments of ceremonial rhetoric are important, as well as those referring to the cultural and political context (cf. Dugan, 2005 , p. 8). As a celebrity in the world of rhetoric, Cicero, who recognizes the specific features of Archias' case, could afford risking a provocative modification of the form and style of his utterance. It is worth emphasizing that the logic of the formal side of the defence evolves and culminates according to the contents of the message of Pro Archia. This synergy of the form and content of Pro Archia is the combination of rhetoric genres which indicates the integration nature of humanism. Cicero presents studia humanitatis as the foundation of the cultural reconstruction of the Roman Republic, combining key areas of the Roman society with their adequate rhetoric kinds: "And, in reality, all the disciplines (artes) that belong to humanity, having a kind of a common connection and quasi-relationship, are linked with one another" (cf. Cicero, 1979, p. 6).

Thus, the composition of the Pro Archia speech includes standard elements of a judicial rhetoric, but epideixis plays the major role in it. Epideixis, or a solemn oration, is understood by Aristotle as a rhetoric kind which focuses on the character of the praised person (praising his humanity) and his moral virtues. Virtue is a habitual ability to do and maintain good, i.e. the ability to perform beautiful and praiseworthy deeds. Aristotle enumerates the following virtues: justice, courage, moderation, generosity, honesty, reason, and wisdom. Justice (in the time of peace) and courage (during a war) are major virtues, as they are the most useful for everyone. Additionally, Aristotle emphasizes the virtue of nobleness, because a noble person tolerates everyone, and he does not get married for money or property. The philosopher believes that absolutely beautiful acts include those which are performed in the name of the homeland, irrespective of one's benefits (cf. Aristoteles, 2009, p. 63).

Comparing to the previous two kinds of a rhetoric art, which aim at encouraging the listener to judge a given case, epideixis does not mainly refer to the judge, but to the spectator (theōrós) and offers him an image of the praised person (basically, epideixis is a performative form). As far as the social development of the ancient Greece is concerned, 
epideixis has the same origin as poiésis. Epideixis, as an archaic cultural phenomenon, performed an important sociogenic function in the societies of ancient Greece. With its performative form of public celebration of the key events in the Greek society's life and death, it served as a medium of common moral narratives creating the society's cultural identity (cf. Sullivan, 1993, p. 115). Gerard Hauser emphasizes an important social and pedagogical aspect of ceremonial rhetoric, showing epideixis as "expressing" and, at the same time, authorizing public morality as something that community members acquire through mimesis (cf. Hauser, 1999, p. 19).

In Pro Archia, in the middle of the trial, Cicero starts to praise the perfection of the poet Archias. Also, he praises stern and understanding judges, as well as senators. Cicero praises the pretor - a brave prince, a righteous consul and a generous patron of the arts; he praises himself as a well-known politician (who, a year before the trial with Archias, made it impossible for Catiline to obtain the title "pater patriae"); he praises communities connected with weapons; and he praises Rome. In other words, he praises moral values of the representatives of important constitutional elements of the Roman social universe, associating the whole collection of virtues of the Aristotelian praising rhetoric with the praised people. Ultimately, however, Pro Archia is a celebration in itself, i.e. a celebration of an epideictic performance as an example demonstration of the values of the study of humanism, which is the central motif of the whole praise by Cicero. This is a praise of what is hidden behind all that perfection which enabled it and which integrates all the enumerated elements of social perfection into an impressive cultural complex of a Roman polis. This is a celebration of "all disciplines" (omnes artes) of the ancient Greek origin of the classical and Hellenistic period (Graecarum artium ac disciplinarum) which cultivate the humanity of individuals and of the whole society.

Thus, a deeper analysis of the context of Pro Archia suggests that Cicero noticed a specific and consistent aspect of epideictic rhetoric which is characterized by a kind of superiority over the judicial and political kind of rhetoric. This special nature of epideixis is already emphasized by Aristotle who, describing the relation of particular rhetoric genres to sections of time, says that: judicial rhetoric refers to the past - to what has already happened or what has not happened; political rhetoric refers to the future - to what should/should not happen; but the epideictic language is, first of all, connected with the present time, although it also refers to the past and to the future (cf. Aristoteles, 2009, p. 39). That is why, epideixis reflects the continuity of the moral narrative of the polis the stage on which the cyclical process of constructing and reconstructing the narrative of cultural identify is taking place. Although Cicero starts from the defence of Archias, he ends with the defence of the community of poets who create a common memory and a common self-assessment of the community. Cicero moves from forensic issues to the cultural and political case. Showing the central role which is played by humanities in the morphogenetic dynamics of the polis results in the fact that humanities enter the political arena. In this way, they ensure the context of political support for the patron of the Roman culture - Lucullus and for the generally threatened ideals of the republic. 


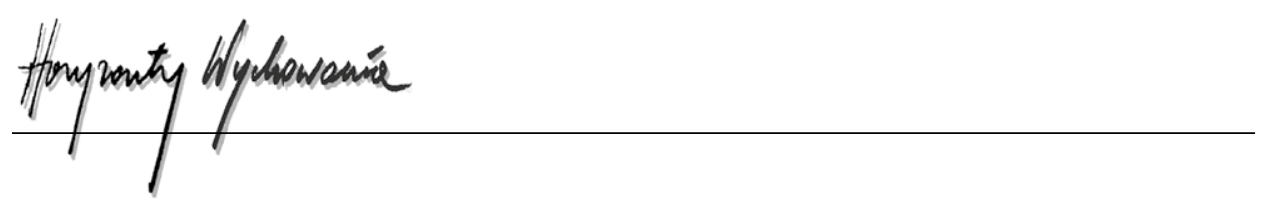

\section{Societas Jesu and the perspectives of the study of humanism}

If we return from Cicero to Petrarch, in the light of what we captured in Pro Archia, we can evaluate how Petrarch's project of humanistic studies reflected its ancient model. Also, it will be interesting to refer to other key inspirations of Petrarch's work. Apart from Cicero and his Pro Archia, Petrarch analysed St. Augustine whose Confessions became a kind of a spiritual compass of his life (cf. Baron, 1985). Without that spiritual layer of Petrarch's personality, we would not have a full image of the interpretation of his intellectual efforts. For Petrarch, studying humanism was a part of a more complex cultivation of human existence, which would not be complete without the spiritual dynamics. In the light of the above, it is possible to better understand the context which refers to the alreadymentioned issue connected with the interpretation of an alternative study of humanism. We cannot deny that the Renaissance humanism contributed to the mass development of educational institutions. An example is an incredibly fast development of Jesuit colleges which offered educational training that was deeply rooted in the study of humanism. The development of humanist studies ended with a gradual overlapping and domestication of humanities in the university curriculum of the 16th century, and, in time, Jesuit colleges were transferred into universities. Contrary to further interpretations, we support the opinion that Petrarch's project referring to studying humanitas was not meant to be an alternative for the scholastic paradigm of education - as a philosophical movement showing the signs of a radical breaking with the medieval thinking. Humanistic studies were not a paradigmatic reversal. It rather seems that humanistic studies were perceived as a completion of the efforts of the cultural reform the elements of which disappeared in the utilitarian professional training. Such a completion was possible due to the return to the ancient model, with its principal focus on humanity, and, as such, it constituted the completion of the divinitatis studies (cf. Kohl, 1992, p. 192; Hankins, 2007, p. 32).

Therefore, Petrarch's humanistic studies were a project of Christian humanism as a way to cultivate humanity, i.e. to cultivate a man as a moral person who, just like humanity, may fully and actively participate in bonum commune. This may explain why Societas Jesu, only eight years after its establishment in 1540, started to build its system of college education, fully adopting the concept of humanistic studies. Humanistic studies described by Petrarch, Salutati and Bruni, were perfectly compliant with the spirituality of St Ignatius. In 1773, Jesuits had more than 700 humanistic schools in the world (cf. O'Malley, 2015, pp. 17-19).

This natural symbiosis of the Jesuit spirituality and the revival of the ancient idea of humanistic studies will probably be more understandable if we realize that the central principle of Jesuits' actions is cura personalis (cf. O'Malley, 2015, p. 12; Jeník, 2015). The concept of cura personalis refers to the idea of lifelong learning that was emphasized by Cicero, and then by Petrarch and other humanists of the Renaissance, which goes far beyond the professional preparation of a student. Cura personalis is the key process in which an individual becomes a personality, developing his/her potential as a being who is free in his/her individuality. In the Jesuit motto: to educate men and women for others 
(cf. O'Malley, 2015, p. 17), we can see the embodiment of the original civil humanism of Cicero (Hankins, 1995, 330).

Finally, if the concept of humanities is analytically connected with humanity, we should consider the anthropological nature of the concept of humanity. From what we learnt about the idea of studying humanism, humanity can be characterized as a dynamic dimension of human existence, a process of developing the potential of an individual as a moral being. Free will is an anthropological condition of personality as a moral being, and the actuality of freedom of a moral being requires the courage to take responsibility. We can see that, in terms of courage for taking responsibility, we come to two features of Aristotle's catalogue, i.e. courage and justice. This leads us to the sociogenic function of studying humanism with its performative function of building the cultural identity. Thus, humanitas is an anthropological element that links individuality with the society.

If we start from the features of humanity, which we have just described, we come to the conclusion that the atrophy of that sociogenic factor in the social universe must inevitably lead to the erosion of the polis. Gradual dissociation of the cultural thread that connects the structure of the society into a functional whole must necessarily be revealed in the increasing polarization and tension among less and less compatible elements of the society. A remedy for this process of degradation are humanistic studies as a lifelong learning project integrated with the life of the polis.

To sum it up, after presenting some crucial elements of the concept of studium humanitas, which we first find in Cicero, and then in the Renaissance receptions of his works - especially in the integration of Petrarch with the Christian spirituality - we can conclude that studium humanitas is cura presonalis. Humanistic studies, with their cultivation of humanity, are the source of social consistency, as well as transformational changes. It is because humanities are the mastic and pulp of the polis.

\section{BIBLIOGRAPHY}

Aristoteles. (2009). Rétorika. (P. Kuklica, Trans.). Thetis.

Baron, H. (1955). Crisis of the early Italian Renaissance. Civic humanism and republican liberty in an age of classicism and tyranny. Princenton University Press.

Baron, H. (1985). Petrarch's secretum. Its making and its meaning. The Medieval Academy of America.

Baron, H. (1989). In search of Florentine civic humanism. Essays on the transition from medieval to modern thought. Princenton University Press.

Burckhardt, J. (1961). The civilisation of the Renaissance in Italy. The New American Library of World Literature, Inc.

Cicero, M.T. (1979). Pro A. Licinio Archia Poeta Oratio. Rede für den Dichter A. Licinius Archias (O. Schönberger, Trans.). Reclam.

Clark, A.C. (1921). The reappearance of the texts of the classics. The Library, 1, 13-42.

Davies, T. (2001). Humanism. Routledge.

Dugan, J. (2005). Making a new man: Ciceronian self-fashioning in the thetorical works. Oxford University Press. 


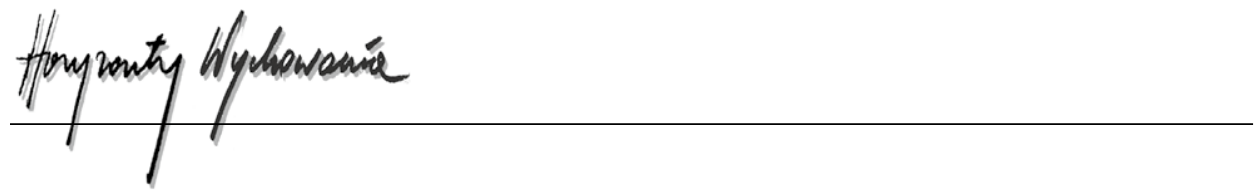

Hankins, J. (1995). The "Baron Thesis" after forty yars and some recent studies of Leonardo Bruni. Journal of the History of Ideas, 56, 309-338.

Hankins, J. (2007). Humanism, scholasticism, and Renaissance philosophy. In J. Hankins (ed.), The Cambridge companion to Renaissance philosophy (pp. 30-48). Cambridge University Press.

Hauser, G.A. (1999). Aristotle on epideictic: The formation of public morality. Rhetoric Society Quarterly, 1, 5-23.

Jeník, L. (2015). K teoretickým východiskám jezuitského vzdelávania. Studia Aloisiana, 6(4), 5-27. Kohl, B.G. (1992). The changing concept of the "studia humanitatis" in the early Renaissance. Renaissance Studies, 6(2), 185-209.

Kristeller, P.O. (1944-1945). Humanism and Scholasticism in the Italian Renaissance. Byzantion, 17, 346-374.

O'Malley, J.W. (2015). Jesuit school of humanities yesterday and today. Studies in The Spirituality of Jesuits, 47(1), 1-33.

Sullivan, D.L. (1993). The ethos of epideictic encounter. Philosophy \& Rhetoric, 2, 113-133.

\section{Copyright and License}

This article is published under the terms of the Creative Commons Attribution - NoDerivs (CC BY- ND 4.0) License http://creativecommons.org/licenses/by-nd/4.0/ 